\title{
Front Matter: Volume 9670
}

, "Front Matter: Volume 9670," Proc. SPIE 9670, Sixth International Conference on Lasers in Medicine, 967001 (22 March 2016); doi: $10.1117 / 12.2230449$

SDIE Event: Sixth International Conference on Lasers in Medicine, 2015, SPIE. Bucharest, Romania 


\title{
PROGRESS IN BIOMEDICAL OPTICS AND IMAGING

\section{Fifth Congress of the World Federation for Laser Dentistry and Sixth International Conference on Lasers in Medicine}

\section{High-end Medicine Based on Laser and Biotechnologies}

\author{
Darinca Carmen Todea \\ Adrian Gh. Podoleanu \\ Virgil-Florin Duma \\ Editors
}

7-9 May 2015

Bucharest, Romania

Organized by

Romanian Society for Lasers in Dentistry (Romania)

University of Medicine and Pharmacy Victor Babes Timisoara (Romania)

The World Federation for Laser Dentistry

Sponsored by

Romanian Society for Lasers in Dentistry (Romania)

The World Federation for Laser Dentistry

Published by

SPIE 
The papers in this volume were part of the technical conference cited on the cover and title page. Papers were selected and subject to review by the editors and conference program committee. Some conference presentations may not be available for publication. Additional papers and presentation recordings may be available online in the SPIE Digital Library at SPIEDigitallibrary.org.

The papers reflect the work and thoughts of the authors and are published herein as submitted. The publisher is not responsible for the validity of the information or for any outcomes resulting from reliance thereon.

Please use the following format to cite material from these proceedings:

Author(s), "Title of Paper," in Sixth International Conference on Lasers in Medicine, edited by Darinca Carmen Todea, Adrian Gh. Podoleanu, Virgil-Florin Duma, Proceedings of SPIE Vol. 9670 (SPIE, Bellingham, WA, 2015) Six-digit Article CID Number.

ISSN: 1605-7422

ISSN: $2410-9045$ (electronic)

ISBN: 9781628418934

Published by

SPIE

P.O. Box 10, Bellingham, Washington 98227-0010 USA

Telephone +1 3606763290 (Pacific Time) · Fax +1 3606471445

SPIE.org

Copyright (C) 2016, Society of Photo-Optical Instrumentation Engineers.

Copying of material in this book for internal or personal use, or for the internal or personal use of specific clients, beyond the fair use provisions granted by the U.S. Copyright Law is authorized by SPIE subject to payment of copying fees. The Transactional Reporting Service base fee for this volume is $\$ 18.00$ per article (or portion thereof), which should be paid directly to the Copyright Clearance Center (CCC), 222 Rosewood Drive, Danvers, MA 01923. Payment may also be made electronically through CCC Online at copyright.com. Other copying for republication, resale, advertising or promotion, or any form of systematic or multiple reproduction of any material in this book is prohibited except with permission in writing from the publisher. The CCC fee code is $1605-7422 / 16 / \$ 18.00$.

Printed in Romania.

Publication of record for individual papers is online in the SPIE Digital Library.

\section{SPIE. DIGITAL}

Paper Numbering: Proceedings of SPIE follow an e-First publication model. A unique citation identifier (CID) number is assigned to each article at the time of publication. Utilization of CIDs allows articles to be fully citable as soon as they are published online, and connects the same identifier to all online and print versions of the publication. SPIE uses a six-digit CID article numbering system structured as follows:

- The first four digits correspond to the SPIE volume number.

- The last two digits indicate publication order within the volume using a Base 36 numbering system employing both numerals and letters. These two-number sets start with 00, 01, 02, 03, 04, $05,06,07,08,09,0 A, 0 B \ldots$. OZ, followed by 10-1Z, 20-2Z, etc. The CID Number appears on each page of the manuscript. 


\title{
Contents
}

\author{
vii Authors \\ ix Conference Committee \\ xiii Introduction
}

\section{SESSION $1 \quad$ LASERS IN DENTISTRY}

967002 Non-invasive diagnostic methods in dentistry (Invited Paper) [9670-41]

967003 Oral vascular malformations: Iaser treatment and management (Invited Paper) [9670-77]

967004 What's new in paediatric dentistry? (Invited Paper) [9670-10]

967005 Value added cleaning and disinfection of the root canal: laser-activated irrigation and laser-induced photoporation (Invited Paper) [9670-25]

967006 Lasers in oral implantology (Invited Paper) [9670-46]

967007 Lasers in oral surgery and implantology (Invited Paper) [9670-111]

967008 Laser therapy and sclerotherapy in the treatment of oral and maxillofacial hemangioma and vascular malformations [9670-3]

967009 Treatments of the oral leukoplakia by laser [9670-18]

$96700 \mathrm{~A}$ The effects of photodynamic laser therapy in the treatment of marginal chronic periodontitis [9670-27]

9670 OB Platelet rich fibrin in jaw defects [9670-33]

$96700 \mathrm{C}$ Assesment of gingival microcirculation in anterior teeth using laser Doppler flowmetry [9670-35]

9670 OD Photodynamic therapy in non-surgical treatment of chronic periodontitis: short term randomized clinical trial study [9670-38]

9670 OE Laser Doppler flowmetry: an early diagnosis instrument in detecting the soft tissue changes that occur during radiotherapy to the head and neck area, clinical case report [9670-45]

$9670 \mathrm{OF}$ The use of laser $\mathrm{CO}_{2}$ in salivary gland diseases [9670-48]

9670 OG Short-term clinical outcomes of laser supported periodontal treatment concept using Er,Cr:YSGG (2780nm) and diode (940 nm): a pilot study [9670-55]

$9670 \mathrm{OH}$ Effect of Nd:YAG laser light on post-extractive socket healing in rats treated with zoledronic acid and dexamethasone [9670-65] 
967000 Practical applications of the diode in dental practice [9670-69]

9670 0J Evaluation of gingival vascularisation using laser Doppler flowmetry [9670-71]

9670 OK Low-Level Laser Therapy (LLLT) for periodontal pockets: a review [9670-100]

$9670 \mathrm{OL}$ Photodynamic therapy in the treatment of epithelial potentially malignant disorders of the mouth: advantages and disadvantages [9670-101]

$96700 \mathrm{M}$ The efficacy of low-level laser treatment in reducing pain and swelling after endodontic surgery: a systematic review [9670-104]

9670 ON Low Level Laser Therapy in the treatment of oral mucositis in cancer patients: systematic review of literature [9670-1 17]

967000 Imunohistological aspects of the tissues around dental implants (Invited Paper) [9670-127]

9670 OP Laser assisted periodontal treatment: from bactericidal effect to local modification of the host response [9670-19]

9670 OQ SEM investigation of Er:YAG laser apical preparation [9670-94]

9670 OR Early diagnosis of incipient caries based on non-invasive lasers [9670-95]

9670 OS Children acceptance of laser dental treatment [9670-87]

SESSION 2 BIOMEDICAL IMAGING, OPTICAL COHERENCE TOMOGRAPHY, AND BASIC SCIENCE

9670 OT En-face optical coherence tomography revival (Invited Paper) [9670-49]

9670 OU Optical imaging for the diagnosis of oral cancer and oral potentially malignant disorders (Invited Paper) [9670-26]

9670 OV Handheld scanning probes for optical coherence tomography: developments, applications, and perspectives (Invited Paper) [9670-1]

9670 OW Assessment of dental plaque by optoelectronic methods [9670-56]

9670 0X Evaluation of Tizian overlays by means of a swept source optical coherence tomography system [9670-88]

9670 OY Mitigation of enamel erosion using commercial toothpastes evaluated with optical coherence tomography [9670-23]

$96700 Z$ OCT evaluation of single ceramic crowns: comparison between conventional and chairside CAD/CAM technologies [9670-90]

967010 OCT and shear-force evaluations of zirconia fixed partial prosthesis processed with a conventional CAD/CAM technology [9670-108] 
967011 All ceramic table tops analyzed using swept source optical coherence tomography [9670-92]

967012 Marginal integrity evaluation of dental composite using optical coherence tomography [9670-106]

967013 Complete denture base assessments using holograms: dimensional alterations after different activation methods [9670-82]

967014 Influence of scanning system and dentist's level of training in the accuracy of digital impressions [9670-28] 


\section{Authors}

Numbers in the index correspond to the last two digits of the six-digit citation identifier (CID) article numbering system used in Proceedings of SPIE. The first four digits reflect the volume number. Base 36 numbering is employed for the last two digits and indicates the order of articles within the volume. Numbers start with 00, 01, 02, 03, 04, 05, 06, 07, 08, 09, 0A, 0B...0Z, followed by 10-1Z, 20-2Z, etc.

Antal, Anca Adriana, 12

Arnabat-Domingeuz, Josep, 06

Avram, Ramona, OA

Băciuț, Grigore, 08

Băciuț, Mihaela, 08

Badea, Iulia, OA

Badea, Mîndra Eugenia, OA

Badea, Victoria, OG

Bălăbuc, Cosmin, $0 Q$

Barbur, loan, 08

Barnes, Frederick, OT

Bianchi, Massimiliano, $\mathrm{OH}$

Borțun, Cristina Maria, OW

Bradu, Adrian, OT, OV, OX, OZ, 10, 11

Bran, Simion, 08

Bussolati, Ovidio, $\mathrm{OH}$

Buțincu, Lavinia, 00

Canjau, Silvana, OC

Capocci, M., 09

Cassimiro-Silva, Patricia Fernandes, OY

Cernat, R., OV

Chifor, loana, OA

Chifor, Radu, OA

Ciolfi, C., OF

Ciurescu, Codruța, OP

Ciurescu, Daniel, OP

Cojocariu, Andreea-Codruta, OW, 12, 13

Corradi, Domenico, $\mathrm{OH}$

Crăciunescu, Emanuela Lidia, OW

Crişan, Bogdan, 08

Crişan, Liana, 08

De Moor, Roeland J. G., 05

de Sabata, Aldo, 13

Del Vecchio, A., 09, OL

Demian, D., OV

Dinu, Cristian, 08

Dobre, G., OV

Dughir, Ciprian, 13

Duma, Virgil-Florin, OK, OV, OW, OX, 0Z, 10, 11, 12, 13

El Sabbagh, RulaFawzi, ON

Fioravanti, M., OF

Gabor, Alin, 0Z, 10, 14

Gaimari, G., 03, 09, 0D, OL

Gomes, Anderson Stevens Leônidas, OY

Govoni, Paolo, $\mathrm{OH}$

Gutknecht, Norbert, OG

Hategan, Simona, 0Z, 14

Hutiu, Gh., OV
Ianes, Emilia, $\mathrm{OB}, \mathrm{OE}$

Ivaşcu, Roxana Victoria, 00

Jivanescu, Anca, 0Z, 14

Kapinchev, Konstantin, OT

Kornblit, R., OD

Lazea, Andreea, OS

Levai, Mihaela-Codrina, OW, 0Z, 10

Libotte, F., OD

Lo Giudice, G., 03

Lo Giudice, R., 09

Locovei, Cosmin, $0 Q$

Loskutova, E., OD

Maestri, Roberta, $\mathrm{OH}$

Magdaş, Andreea, 08

Maia, Ana Marly Araújo, OY

Marcauteanu, Corina, 0X, 11

Meire, Maarten A., 05

Mergoni, Giovanni, $\mathrm{OH}$

Merigo, Elisabetta, $\mathrm{OH}$

Miron, Mariana I., OC, OE

Mitre, lleana, 08

Mohsen, M., 09

Moldovan, Iuliu, 08

Moldoveanu, Lucia Elena, 0

Monteiro, Gabriela Queiroz de Melo, OY

Moraru, Simona, 00

Moshari, Amirabbas, OM

Namour, Samir, $\mathrm{OH}$

Negrutiu, Meda-Lavinia, OV, OW, OX, 0Z, 10, 11 ,

$12,13,14$

Nica, Diana, OB

Nimigean, Vanda Roxana, 00

Nimigean, Victor, $0 \mathrm{O}$

Odor, Alin Alexander, 0G, Ol

Palaia, G., 03, 09, OD, OF, OL

Passerini, Pietro, $\mathrm{OH}$

Petre, L. C., OE

Podoleanu, Adrian Gh., OT, OV, OW, OX, 0Z, 10, 11 , 12

Poll, Alexandru, 00

Popovschi, Ana Maria, 13

Pribac, Valentin, OK

Pricop, Marius, $\mathrm{OB}$

Răduță, Aurel, $O Q$

Rocchetti, F., 03, OF

Romeo, U., 03, 09, OD, OF, OL

Rotar, Horativ, 08

Russo, C., OD, OL

Sala, Roberto, $\mathrm{OH}$ 
Sălăvăstru, Dan Ionut, 00

Selting, Wayne J., ON

Sinescu, Cosmin, OV, OW, OX, OZ, 10, 11, 12, 13, 14

Şipoş, C., OJ

Stan, Adrian-Tudor, 12

Stoica, Eniko Tunde, OX, 11

Tenore, G., 03, OD, OF, OL

Teslaru, Silvia, OP

Todea, Carmen D., 02, OC, OJ, OK, OQ, OR, OS

Topala, Florin lonel, OV, OW, OX, OZ, 10, 11, 12, 13

Tribolati, L., 09

Văcăraş, Sergiu, 08

Vatanpour, Mehdi, OM

Velescu, A., OJ, OR

Vescovi, Paolo, $07, \mathrm{OH}$

Violant, Deborah, OG

Vitale, M. C., 04

Vitez, B., OJ, OR

Yoshida, K., OU

Zaharia, Cristian, 0Z, 10, 14

Zakershahrak, Mehrsa, OM

Zetu, Liviu, OP 


\section{Conference Committee}

Conference Chairs

Darinca Carmen Todea, University of Medicine and Pharmacy Victor Babes Timisoara (Romania)

Adrian Gh. Podoleanu, University of Kent (United Kingdom)

Virgil-Florin Duma, Aurel Vlaicu University of Arad (Romania)

\section{Conference Committee}

Darinca Carmen Todea, University of Medicine and Pharmacy Victor Babes Timisoara (Romania)

Umberto Romeo, Università degli Studi di Roma La Sapienza (Italy)

Adrian Gh. Podoleanu, University of Kent (United Kingdom)

Raica Marius, University of Medicine and Pharmacy Victor Babes Timisoara (Romania)

Virgil-Florin Duma, Aurel Vlaicu University of Arad (Romania) and Politehnica University of Timisoara (Romania)

Scientific Committee

Darinca Carmen Todea, University of Medicine and Pharmacy Victor Babes Timisoara (Romania)

Roeland De Moor, Universiteit Gent (Belgium)

Peter Verheyen, Private Practice (Belgium)

Adrian Gh. Podoleanu, University of Kent (United Kingdom)

Josep Arnabat, Universitat de Barcelona (Spain)

Antoni Espana, Universitat de Barcelona (Spain)

Virgil-Florin Duma, Aurel Vlaicu University of Arad (Romania) and Politehnica University of Timisoara (Romania)

Adrian Mănescu, Università Politecnica delle Marche (Italy)

Roly Konbilt, Università degli Studi di Roma La Sapienza (Italy)

Umberto Romeo, Università degli Studi di Roma La Sapienza (Italy)

Alessandro Del Vecchio, Università degli Studi di Roma La Sapienza (Italy)

Gianfranco Semez, Private Practice (Italy)

Peter Fahlstedt, Karolinska Institute, Stockholm (Sweden)

Norbert Gutknecht, RWTH Aachen Universität Hospital (Germany)

Sharonit Sahar Helft, Hebrew University-Hadassah of Jerusalem (Israel)

Samir Nammour, University of Leige (Belgium)

Meda Lavinia Negruțiu, University of Medicine and Pharmacy Victor Babes (Romania)

Cosmin Sinescu, University of Medicine and Pharmacy Victor Babes (Romania) 
Adam Stabholz, Hebrew University-Hadassah of Jerusalem (Israel)

Dimitris Straka, Aristotle University of Thessaloniki (Greece)

Paolo Vescov, Università degli Studi di Parma (Italy)

Marina Vitale, Università degli Studi di Pavia (Italy)

Kenji Yoshida, Aichi Gakuin University (Japan)

Denise Zezell, Cidade Universitária S.A. (Brazil) and Universidade de São Paulo (Brazil)

\section{Session Chairs}

1 Photodynamic Therapy in Dentistry

Marina Vitale, Università degli Studi di Pavia (Italy)

Peter Verheyen, Private Practice (Belgium)

2 Lasers in Oral Surgery \& Implantology

Darinca Carmen Todea, University of Medicine and Pharmacy Victor Babes Timisoara (Romania)

Adam Stabholz, Hebrew University-Hadassah of Jerusalem (Israel)

Mariana Miron, University of Medicine and Pharmacy Victor Babes Timisoara (Romania)

Antoni Espana, Universitat de Barcelona (Spain)

Dimitris Strakas, Aristotle University of Thessaloniki (Greece)

Norbert Gutknecht, RWTH Aachen Universität Hospital (Germany)

Sharonit Sahar Helft, Hebrew University-Hadassah of Jerusalem (Israel)

Kenji Yoshida, Aichi Gakuin University (Japan)

3 Lasers in Periodontology

Umberto Romeo, Università degli Studi di Roma La Sapienza (Italy)

Samir Nammour, University of Leige (Belgium)

$4 \quad$ Lasers in Endodontics

Paolo Vescovi , Università degli Studi di Parma (Italy)

Josep Arnabat, Universitat de Barcelona (Spain)

Alessandro Del Vecchio, Università degli Studi di Roma La Sapienza (Italy)

5 Lasers in Conservative Dentistry and Esthetics

Roeland De Moor, Universiteit Gent (Belgium)

Roly Konbilt, Università degli Studi di Roma La Sapienza (Italy)

6 Optical Coherence Tomography

Denise Zezell, Cidade Universitária- USP (Brazil)

Adrian Gh. Podoleanu, University of Kent (United Kingdom) 
7 Low Level Laser Therapy in Dentistry

Peter Fahlstedt, Karolinska Institute, Stockholm (Sweden)

Lajos Gaspar, Private Practice (Hungary)

8 Lasers in General Dentistry

Meda Lavinia Negruțiu, University of Medicine and Pharmacy Victor Babes (Romania)

Gianfranco Semez, Private Practice (Italy)

9 Basic Science and Optoelectronics

Virgil-Florin Duma, Aurel Vlaicu University of Arad (Romania) and Politehnica University of Timisoara (Romania)

Adrian Mănescu, Università Politecnica delle Marche (Italy) 


\section{Introduction}

The Fifth Congress of the World Federation for Laser Dentistry and Sixth International Conference on Lasers in Medicine: High-end Medicine based on Laser and Biotechnologies, Bucharest, Romania proved to be a highly diversified and interesting meeting. One of the major goals of this congress was to establish new scientific and professional relationships, as well as to exchange the latest results regarding scientific research and the clinical applications of the laser therapy. The synergism of practical and technological aspects for addressing and advancing laser clinical applications was clear and has proven to be an excellent choice, providing a unique and useful forum. The congress has been an innovative and a comprehensive overview of the latest research developments in laser dentistry. Numerous topics were presented at this international forum by outstanding invited speakers, while others had the form of oral communications and posters at the dedicated sessions.

As a novelty, basic science and opto-electronics, optical coherence tomography, and implantology had dedicated sections. Moreover, this congress aimed to attract well-known researchers, and practitioners, as well as PhD students, young doctors and even final year undergraduate students. It also included hands-on workshops, lectures of prestigious personalities from all around the world and scientific papers and posters which represented a great opportunity to update our knowledge. The exhibitions presented a wide range of laser devices used in dentistry and oral surgery but also some of the latest equipment and instruments used in modern medicine.

Bucharest, the Romanian capital also known as the "Little Paris" captivated all the participants with its architectural and historical beauty; and also with its new face looking forward to the future.

We look forward to the next ICLM conference and to the next WFLD Congress and wish for additional and advanced progress in the field of lasers in dentistry research. We hope that such developments will be presented and will continue to expand and improve the objectives of the future conferences.

The congress chairs would like to thank the speakers, the organizing committee, the scientific and advisory committees, the session chairs, and most importantly the SPIE staff for their many contributions for making the ICLM conference and WFLD Congress a real success.

\section{Darinca Carmen Todea Adrian Gh. Podoleanu Virgil-Florin Duma}

